\title{
Carbon Dioxide as a Growth Factor for Mutants of Escherichia coli
}

\author{
By H. P. CHARLES AND GILLIAN A. ROBERTS \\ Department of Microbiology, the University of Reading
}

(Accepted for publication 25 September 1967)

\begin{abstract}
SUMMARY
This report shows that some auxotrophic mutants of Escherichia coli can grow on a minimal medium without growth factors when the gas phase is supplemented with carbon dioxide. Mutants which respond to $\mathrm{CO}_{2}$ are called $\mathrm{CO}_{2}$ mutants. The $\mathrm{CO}_{2}$ mutants of $E$. coli resemble those already known in Neurospora. When the gas phase is not supplemented with $\mathrm{CO}_{2}$ most of the mutants respond to other specific growth factors such as arginine, uracil, adenine, succinate or isoleucine + valine, depending upon the locus of their mutation. One mutant is an obligate $\mathrm{CO}_{2}$ mutant. The $\mathrm{CO}_{2}$ effects shown by these mutants are discussed in relation to the general problem of $\mathrm{CO}_{2}$ effects in micro-organisms.
\end{abstract}

\section{INTRODUCTION}

Carbon dioxide is necessary for the growth or the initiation of growth of bacteria and other micro-organisms (Valley \& Rettger, 1927; Rockwell \& Highberger, 1927). This is sometimes referred to as 'the $\mathrm{CO}_{2}$ effect' (e.g. Wilson \& Miles, I964). $\mathrm{CO}_{2}$ also has other interesting effects. For example, it causes morphogenetic changes in organisms as different as bacteria (Ivanovics, 1937), fungi (Bartnicki-Garcia \& Nickerson, 1962) and coelenterates (Loomis, 196I). Recently, a new kind of $\mathrm{CO}_{2}$ effect was discovered in which $\mathrm{CO}_{2}$ acts as a growth factor for mutants of the mould Neurospora (Charles, 1962; Reissig \& Nazario, 1962; Charles \& Broadbent, 1964; Broadbent \& Charles, 1965). The mutants require up to $30 \% \mathrm{CO}_{2}(\mathrm{v} / \mathrm{v})$ in the gas phase for growth to occur, whereas the wild type requires less $\mathrm{CO}_{2}$ than is present in ordinary air $(0.02-0.04 \%)$. When these mutants are not supplied with supplementary $\mathrm{CO}_{2}$ they behave as normal auxotrophic mutants, each requiring a particular growth factor such as arginine, adenine, uridine or succinate, depending upon the site of the mutation. Mutants which are stimulated by $\mathrm{CO}_{2}$ are called $\mathrm{CO}_{2}$ mutants (Charles \& Broadbent, 1964). The way in which $\mathrm{CO}_{2}$ stimulates the growth of the mutants has not been definitely established, and the mechanism may be different in different mutants. A problem arising from the research with the Neurospora mutants was whether the effects observed are peculiar to Neurospora, or whether they are of wider occurrence. This report shows that $\mathrm{CO}_{2}$ mutants of the bacterium Escherichia coli occur. The bacterial mutants are described and compared with those of Neurospora. Apart from their intrinsic interest, $\mathrm{CO}_{2}$ mutants may be useful because analysis of the mechanism of the $\mathrm{CO}_{2}$ stimulation may contribute to the understanding of $\mathrm{CO}_{2}$ effects in other organisms. 


\section{METHODS}

The following strains of Escherichia coli $\mathrm{K}$ I 2 were used:

F- AB I62I (thi-, $\mathrm{mtl}^{-}, \mathrm{xyl}^{-}, \mathrm{str}^{r}, \mathrm{ara}^{-}, \mathrm{gal}^{-}, \mathrm{lac}^{-}$)

Hfr AB $2575\left(\right.$ ilv $^{-}$, str $\left.^{*}\right)$ which transfers genes in the order $O$-ara, lac, gal, ...

Hfr P I0 $\left(t^{-} r^{-}, l e u^{-}, t h i^{-}, T_{6}^{s}, s t r^{\circ}\right)$ transferring genes in the order $O-t h i-m e t-m t l . .$. Hfr B $7\left(\right.$ met $\left.^{-}, s t r^{s}, T_{6}^{s}\right)$ transferring genes in the order $O$-try-his...

Strains AB I62I and AB 2575 were kindly provided by Professor E. A. Adelberg, and strains $P$ IO and $B$

The minimal media used were those described by Vogel \& Bonner (1956), and Davis \& Mingioli (1950). Unless stated otherwise the minimal media contained glucose $(0.5 \%$ autoclaved separately) and were supplemented with thiamine (2 mg./1.) because the $\mathrm{F}^{-}$strain requires thiamine. The medium was solidified when necessary with Difco Bacto agar (12 g./1.). The complete medium contained the following (g./1.:) tryptone (Oxoid), Io; yeast extract (Difco), 5; $\mathrm{KH}_{2} \mathrm{PO}_{4}, 3 ;$ glucose, 5 ; agar, I5 (when required).

Cultures were grown and maintained on slopes of complete agar medium. The temperature of incubation was $37^{\circ}$. Strains to be used in mating experiments were streaked on plates of complete medium to give discrete colonies and stored at $4^{\circ}$. Single colonies were picked for the experiments; their phenotypes were checked before use.

Nutritional requirements of mutants were determined by the auxanographic method (Pontecorvo, 1949); about $3 \times 10^{6}$ bacteria $/ \mathrm{ml}$. were dispersed in the minimal agar medium.

When it was required to incubate cultures in a gas phase of air supplemented with $\mathrm{CO}_{2}$ the procedure was as follows. Cultures in Petri dishes (lids removed) were stacked in 51 . vacuum desiccators in layers of three with the agar facing downwards, each dish resting equally on 2 dishes below it; $\mathrm{CO}_{2}$ was generated by the action of hydrochloric acid on marble chips in a Kipp apparatus, and allowed to enter each desiccator after the appropriate amount of air had been withdrawn. Removal of the lids of the Petri dishes was later found to be unnecessary. Equally good $\mathrm{CO}_{2}$ effects were obtained when the bacteria were dispersed throughout the agar as when they were spread on the surface.

Most $\mathrm{CO}_{2}$ mutants will grow without a supplement of $\mathrm{CO}_{2}$ when other specific growth factors such as succinate or arginine are added to the minimal medium; they will be referred to as $\mathrm{CO}_{2}$ mutants or as succinate, arginine, etc., mutants, as convenient.

The loci of the mutations were determined by the interrupted mating technique (Hayes, Jacob \& Wollman, 1956) as follows. Overnight broth cultures of the strains to be mated were diluted I/IO in fresh broth at $37^{\circ}$ and $10 \mathrm{ml}$. volumes were incubated in a shaking water bath for about $\mathrm{I} .5 \mathrm{hr} ; 0.5 \mathrm{ml}$. of the $\mathrm{Hfr}$ culture and $9.5 \mathrm{ml}$. of the $\mathrm{F}^{-}$culture were then mixed in a $50 \mathrm{ml}$. Erlenmeyer flask and the mixture gently rocked in the water bath for the duration of the experiment. Samples (0. I ml.) of the mating mixture were taken immediately after mixing and then at $5 \mathrm{~min}$. intervals, diluted 100 times in minimal medium without glucose and agitated for $60 \mathrm{sec}$. by using a rotary mixer to stop the mating process. Samples ( $0.1 \mathrm{ml}$.) of the suspensions 
were then plated in duplicate on selective media to determine the numbers of recombinants. Transduction experiments were done as described by Glansdorff (I965).

\section{Isolation of $\mathrm{CO}_{2}$ mutants}

Experiments I-4. Mutations were induced in Escherichia coli strain AB I62I with ultraviolet radiation and the mutants enriched by penicillin treatment (Gorini \& Kaufman, 1959). The procedure included a $16-\mathrm{I} 8 \mathrm{hr}$ period of intermediate incubation during which the bacteria multiplied, and their mutations became phenotypically expressed, before they were treated with penicillin. The medium used for this intermediate incubation was varied in Exp. I-4 (see Table I) to allow for the possibility that some media might select for or against some kinds of $\mathrm{CO}_{2}$ mutants. For example, in Expt. 3, $\mathrm{CO}_{2}$ was used to supplement the minimal medium by slowly bubbling a gas mixture composed of $70 \%(\mathrm{v} / \mathrm{v})$ air $+30 \%(\mathrm{v} / \mathrm{v}) \mathrm{CO}_{2}$ through the incubating suspension. After penicillin treatment $\mathrm{CO}_{2}$-requiring mutants were detected as follows. Suitable dilutions of the washed bacterial suspensions were spread on complete medium to give about 200 colonies per plate after incubation. After incubation for $24 \mathrm{hr}$ the colonies on each plate were printed on to two plates of minimal medium by the replica plating technique (Lederberg \& Lederberg, 1952). One of each pair of plates was incubated in ordinary air and the other in a gas phase of air $+20 \%(\mathrm{v} / \mathrm{v}) \mathrm{CO}_{2}$. After incubation for 24-72 hr the pairs of plates were compared and colonies which had grown only in the presence of $20 \% \mathrm{CO}_{2}$ were purified by streaking and tested further.

Experiment 5. Mutations were induced in Escherichia coli AB I62 I with $N$-methyl- $N$ nitroso- $N^{\prime}$-nitroguanidine (MNNG) by using a modification of the method of Goodgal, Margolin \& Sanderson (1964). Overnight growth in broth (5 ml.) was washed and resuspended in the same volume of minimal medium enriched with $2.5 \%(\mathrm{v} / \mathrm{v}) \mathrm{com}$ plete medium. A sample, 0.1 or $0.2 \mathrm{ml}$., of an unsterilized solution of MNNG (4 mg./ ml.) was added and the suspension incubated for 30-60 min. Complete medium ( $4.5 \mathrm{ml}$.) was added and incubation continued for about $2 \mathrm{hr}$. Suitable dilutions were then spread on plates of complete medium and incubated for 3-5 days in a gas phase of air $+20 \%(\mathrm{v} / \mathrm{v}) \mathrm{CO}_{2}$. The colonies which grew on each plate were printed on to two plates of minimal medium and $\mathrm{CO}_{2}$ mutants detected as in Expt. $\mathrm{I}-4$. Enrichment of mutants was not necessary.

\section{RESULTS}

Table I shows the results of the mutant isolation experiments. As described in Methods, various supplemented media were used for the period of intermediate incubation in the penicillin selection procedure. The results in Table I show that the kinds of mutants obtained depended upon the medium used for the period of intermediate incubation. Thus the only medium which gave a good yield of histidine mutants and isoleucine + valine mutants was minimal medium through which a mixture of $70 \%$ $(\mathrm{v} / \mathrm{v})$ air $+30 \%(\mathrm{v} / \mathrm{v}) \mathrm{CO}_{2}$ was slowly and continuously bubbled. Mutants requiring arginine, a pyrimidine, or arginine $+\mathbf{a}$ pyrimidine, were only obtained when the minimal medium was supplemented with arginine + uridine + adenine.

A gas phase of $80 \%(\mathrm{v} / \mathrm{v})$ air $+20 \%(\mathrm{v} / \mathrm{v}) \mathrm{CO}_{2}$ was the most stimulatory for the $\mathrm{CO}_{2}$ mutants of Escherichia coli. Higher proportions of $\mathrm{CO}_{2}$ were not tested because they inhibited the parental strain. All but one of the mutants responded to other growth factors when a supplement of $\mathrm{CO}_{2}$ was not provided. The mutants were of at 
least Io kinds, distinguishable by their responses to growth factors other than $\mathrm{CO}_{2}$. As with Neurospora the response of some of the $E$. coli mutants to $\mathrm{CO}_{2}$ was annulled by certain metabolites. Mutants responding to a particular growth factor showed the same pattern of response to precursors of that growth factor (when available), suggesting that their mutations were at the same locus. One mutant of each kind was chosen for genetical studies. Nutritional and genetical data are shown in Table 2. Because nutritional experiments were done on solid media, quantitative data for the stimulatory effect of $\mathrm{CO}_{2}$ and other growth factors are not available, but Table 2 shows the time taken by the various mutants when incubated in $20 \% \mathrm{CO}_{2}$ to equal the growth of the parental strain after $18 \mathrm{hr}$. The different kinds of mutants will now be considered individually.

Table I. Escherichia coli: $\mathrm{CO}_{2}$ mutants obtained in mutant isolation experiments

\begin{tabular}{|c|c|c|c|c|}
\hline $\begin{array}{c}\text { Experiment } \\
\text { no. }\end{array}$ & $\begin{array}{l}\text { Mutagenic } \\
\text { treatment }\end{array}$ & $\begin{array}{l}\text { Supplement added to } \\
\text { minimal medium for } \\
\text { the period of } \\
\text { intermediate cultivation }\end{array}$ & $\begin{array}{c}\text { Kinds of } \mathrm{CO}_{2} \\
\text { mutants obtained* }\end{array}$ & $\begin{array}{l}\text { No. of } \\
\text { mutants of } \\
\text { each kind } \\
\text { obtained }\end{array}$ \\
\hline I & & $\begin{array}{l}\text { Nutrient broth } \\
(5 \% \mathrm{v} / \mathrm{v})\end{array}$ & $\begin{array}{l}\text { Purine } \\
\text { Succinate } \\
\text { Isoleucine + valine }\end{array}$ & $\begin{array}{l}4 \\
2 \\
\text { I }\end{array}$ \\
\hline 2 & $\begin{array}{l}\text { U.v. irradiation } \\
\text { followed by } \\
\text { penicillin }\end{array}$ & $\begin{array}{l}\text { Yeast extract + yeast } \\
\text { nucleic acid + tryptone } \\
\text { (I00 mg./l. of each) }\end{array}$ & $\begin{array}{l}\text { Purine } \\
\text { Succinate } \\
\text { Isoleucine + valine }\end{array}$ & $\begin{array}{l}\mathbf{I} \\
\mathbf{I} \\
\mathbf{I}\end{array}$ \\
\hline 3 & $\begin{array}{l}\text { selection } \\
\text { procedure }\end{array}$ & $\begin{array}{l}\text { No supplement, but } \\
\text { medium was gassed } \\
\text { with a mixture of } 30 \% \\
\mathrm{CO}_{2}+70 \% \text { air }\end{array}$ & $\begin{array}{l}\text { Histidine } \\
\text { Succinate } \\
\text { Isoleucine + valine }\end{array}$ & $\begin{array}{r}5 \\
\text { I } \\
\text { I I }\end{array}$ \\
\hline 4 & & $\begin{array}{l}\text { Arginine }+ \text { adenine }+ \\
\text { uridine (10 } \mathrm{mg} . / 1 . \text { of } \\
\text { each) }\end{array}$ & $\begin{array}{l}\text { Purine } \\
\text { Arginine } \\
\text { Pyrimidine } \\
\text { Arginine + pyrimidine }\end{array}$ & $\begin{array}{l}7 \\
\text { I } \\
\text { I } \\
\text { I }\end{array}$ \\
\hline 5 & $\begin{array}{l}\text { MNNG } \dagger \text { without } \\
\text { penicillin } \\
\text { selection }\end{array}$ & Not applicable & $\begin{array}{l}\text { Purine } \\
\text { Succinate } \\
\text { Isoleucine+valine } \\
\text { Methionine, } \\
\text { Obligate } \mathrm{CO}_{2} \text { mutant }\end{array}$ & $\begin{array}{l}\text { I } \\
2 \\
4 \\
\text { I } \\
\text { I }\end{array}$ \\
\hline
\end{tabular}

* The mutants are classified according to their nutritional requirements when incubated in ordinary air.

$\dagger$ MNNG $=N$-methyl- $N$-nitroso- $N^{\prime}$-nitroguanidine.

\section{Purine mutants}

When the gas phase was not supplemented with carbon dioxide the purine mutants were stimulated by adenine, guanine, hypoxanthine or xanthine. This showed that they have a defect in one of the enzymes synthesizing the purine ring. When grown in minimal medium in the presence of $20 \% \mathrm{CO}_{2}$, or in complete medium, for 3 days, the mutants produced a yellowish brown coloration. The crude culture filtrate of a mutant grown for $24 \mathrm{hr}$ in minimal medium supplemented with a growth-limiting concentration of hypoxanthine $(5 \mathrm{mg}$./1.)s howed a strong ultraviolet absorption maximum at $300 \mathrm{~m} \mu$ which was not shown by a similar filtrate of the culture in which the parental strain had grown. This pigment is probably 5 -aminoimidazole ribonucleotide (AIR). 
or a derivative, which has an absorption maximum at $305 \mathrm{~m} \mu$ (Love \& Gots, 1955). Interrupted mating experiments showed that the mutations mapped between the lac and gal loci in the region of the adef locus (Stouthamer, de Haan \& Nijkamp, 1965). Gots (1965) showed that the enzyme specified by this locus catalyses the conversion of AIR to CAIR (5-aminoimidazole-4-carboxylic acid ribonucleotide). This is the only $\mathrm{CO}_{2}$-incorporation reaction in purine biosynthesis, and the explanation of the $\mathrm{CO}_{2}$ effect shown by these mutants may be that the carboxylating enzyme in the mutants requires a higher concentration of $\mathrm{CO}_{2}$ for activity than does this enzyme in the parental strain. The purine mutants were inhibited by aspartate when growing in $\mathrm{CO}_{2}$, but they were not inhibited by aspartate when any one of the stimulatory purines was present. Some of the Neurospora $\mathrm{CO}_{2}$ mutants also respond to purines, excrete a similar pigment, and map at a locus which may specify the carboxylating enzyme (Broadbent \& Charles, 1965).

\section{Table 2. Escherichia coli: some characteristics of $\mathrm{CO}_{2}$ mutants}

\begin{tabular}{|c|c|c|c|c|}
\hline $\begin{array}{l}\text { Designation } \\
\text { of mutants } \\
\text { selected } \\
\text { for study }\end{array}$ & $\begin{array}{l}\text { Locus of the } \\
\text { mutation }\end{array}$ & $\begin{array}{c}\text { Time }(\mathrm{hr}) \text { required } \\
\text { in } 20 \%(\mathrm{v} / \mathrm{v}) \mathrm{CO}_{2} \\
\text { to equal the growth } \\
\text { produced by the } \\
\text { parent strain after } \\
\text { I } 8 \mathrm{hr}\end{array}$ & $\begin{array}{l}\text { Nutritional requirement } \\
\text { when incubated in ordinary } \\
\text { air without } \\
\text { a supplement } \\
\text { of } \mathrm{CO}_{2}\end{array}$ & $\begin{array}{l}\text { Growth in } \mathrm{CO}_{2} \\
\text { inhibited by }\end{array}$ \\
\hline A 17 & pur-E (ade-f) & 18 & Purines & - \\
\hline S 19 & suc & $18-36^{*}$ & $\begin{array}{l}\text { Succinate, 2-oxoglutarate, } \\
\text { lysine + methionine }\end{array}$ & Aspartate \\
\hline L 23 & Not known & $18-48^{*}$ & $\begin{array}{l}\text { Isoleucine }+ \text { valine, iso- } \\
\text { leucine }+\alpha \text {-keto- } \\
\text { isovalerate }\end{array}$ & $\begin{array}{l}\text { Aspartate, } \\
\text { purines }\end{array}$ \\
\hline H 13 & Not known & $\begin{array}{c}36 \\
\text { (18 hr in presence } \\
\text { of nicotinic acid) }\end{array}$ & Histidine & $\begin{array}{l}\text { Aspartate, } \\
\text { purines }\end{array}$ \\
\hline MI2 & $p y r-F$ & 36 & Pyrimidines & - \\
\hline B 22 & cap & 48 & Arginine or citrulline & Pyrimidines \\
\hline AP 2I & cap & 18 & $\begin{array}{l}\text { Arginine or citrulline }+ \\
\text { a pyrimidine }\end{array}$ & Pyrimidines \\
\hline $45-I$ & $\begin{array}{l}\text { Not deter- } \\
\text { mined }\end{array}$ & 18 & Methionine or cysteine & Aspartate \\
\hline 'Unknown' & $\begin{array}{l}\text { Not deter- } \\
\text { mined }\end{array}$ & 36 & Unknown & $\begin{array}{l}\text { Purines, } \\
\text { histidine, } \\
\text { tyrosine }\end{array}$ \\
\hline
\end{tabular}

\section{Isoleucine + valine mutants}

The isoleucine + valine $\mathrm{CO}_{2}$ mutants are especially interesting because a $\mathrm{CO}_{2}$ fixation reaction does not occur in the biosyntheses of isoleucine and valine. The only reaction in the biosynthetic sequences in which $\mathrm{CO}_{2}$ takes part is a decarboxylation. The genetics and biochemistry of isoleucine + valine mutants have been studied in detail, especially by Ramakrishnan \& Adelberg (1964, I965a,b). The double amino acid requirement arises because the same four enzymes catalyse the last four reactions in the biosyntheses of both isoleucine and valine. The four genes specifying these enzymes are closely linked and are probably adjacent on the bacterial genome. The $\mathrm{CO}_{2}$ mutants of Escherichia coli map in this region in interrupted mating experiments. It was not possible to determine by nutritional experiments which reaction is defective 
in the mutants because most of the intermediates are not available. However, the last enzyme of the sequence must be functional because the mutants grow when supplied with isoleucine $+\alpha$-keto-isovalerate, the latter substance being the immediate precursor of valine. The growth response to $\mathrm{CO}_{2}$ was inhibited by purines and aspartate, which did not inhibit the parental strain and did not inhibit the mutant when it was growing in the presence of isoleucine + valine. In Neurospora, $\mathrm{CO}_{2}$ mutants responding to isoleucine + valine were not obtained, despite several large mutant-isolation experiments.

\section{Succinate mutants}

Six Escherichia coli mutants required succinate when the gas phase was not supplemented with $\mathrm{CO}_{2}$. These mutants have not all been studied in detail, and they may differ amongst themselves. The important facts are as follows. In the presence of glucose the mutants responded to $\mathrm{CO}_{2}$, succinate or 2-oxoglutarate. When glucose was omitted from the medium the mutants did not use succinate or 2-oxoglutarate as carbon and energy sources, but the parental strain did. The mutants did not grow when other Krebs-cycle intermediates, or acetate, were supplied as carbon sources, even when succinate $(50 \mathrm{mg}$./1.) was present, or when the gas phase contained $20 \%$ (v/v) $\mathrm{CO}_{2}$, whereas the parental strain used several of the Krebs-cycle intermediates. These observations show that neither succinate nor $\mathrm{CO}_{2}$ substituted fully for the product of the defective enzyme(s).

The mutants also grew in minimal medium when supplied with lysine + methionine, instead of succinate or $\mathrm{CO}_{2}$, whether or not glucose was present. This suggested that the mutants may be defective in the synthesis of succinyl-CoA, which is an intermediate in the biosynthesis of lysine and methionine (Gilvarg, 1957; Rowbury \& Woods, 1964). The fact that succinate was stimulatory only in the presence of glucose may indicate that the mutants required glucose to make acetyl-CoA, which might be used in turn for converting succinate to succinyl-CoA.

Succinate mutants similar to those described here have been isolated by other workers, who did not examine the effect of $\mathrm{CO}_{2}$ on their mutants. Davis et al. (I959) described a mutant of Escherichia coli which required succinate or lysine + methionine + threonine for growth. It differed from our mutants in requiring threonine and in failing to respond to 2-oxoglutarate. Because it responded to succinate but not to 2-oxoglutarate they suggested that the mutant might be blocked in the conversion of 2-oxoglutarate to succinate. Davis et al. (1959) showed that their mutant grew on minimal medium, and did not require succinate or lysine + methionine + threonine when it was incubated anaerobically in glucose minimal medium. They concluded that in the parental strain succinate could be formed from glucose anaerobically by reduction of 4-carbon acids, but aerobically only by oxidation of 2-oxoglutarate. Stouthamer (1967) showed that succinate mutants of an Aerobacter species also grew anaerobically in minimal medium without succinate. The succinate mutants described in the present paper show the same effect. Interpretation of the growth-promoting effect of anaerobic conditions requires caution because some succinate mutants may be $\mathrm{CO}_{2}$ mutants and growth on minimal medium in anaerobic jars may be a response to $\mathrm{CO}_{2}$, either added deliberately as a mixture of $95 \%(\mathrm{v} / \mathrm{v}) \mathrm{H}_{2}+5 \%(\mathrm{v} / \mathrm{v}) \mathrm{CO}_{2}$ (Stouthamer, I967) or produced by the bacterial cultures themselves. The fact that the gas phase of the cultures was $\mathrm{O}_{2}$-free may be irrelevant. Experiments which we have done to 
determine whether $\mathrm{CO}_{2}$ is responsible for the stimulatory effect of anaerobic conditions have been inconclusive because of technical difficulties.

Stouthamer (1967) found that the Aerobacter mutants were of 2 kinds, one able and the other unable to use succinate as a source of carbon and energy. He concluded that one kind of mutant was blocked in the decarboxylation of 2-oxoglutarate, but that the nature of the lesion in the other kind was unknown. Back \& Westaway (1962) also described a mutant of Escherichia coli which required lysine + methionine, but they did not state whether it responded to succinate. Various characteristics of the mutants of Stouthamer (1967) and Back \& Westaway (1962) are indicative of $\mathrm{CO}_{2}$ effects. Thus the latter authors say that although their mutant required lysine + methionine for growth, it actually synthesized considerably more lysine and methionine than was available from the medium. Stouthamer (1967) found that growing bacteria oxidized glucose completely, but that washed suspensions only partially oxidized glucose. He also found that the greater the number of bacteria in the inoculum then the shorter the lag period before growth began on medium containing lysine + methionine. All these effects may be due to accumulation of $\mathrm{CO}_{2}$ in the growth medium by the bacteria with a resulting stimulation of metabolic activity and growth.

The mechanism by which $\mathrm{CO}_{2}$ stimulates the mutants is not understood. $\mathrm{A} \mathrm{CO}_{2^{-}}$ fixation step is involved in several reactions leading to the formation of compounds having 4 carbon atoms, and it is possible that high concentrations of $\mathrm{CO}_{2}$ stimulate one of these reactions or bring an alternative one into operation. If this be the case, however, malate and oxalacetate should be stimulatory, because they are products of some of the $\mathrm{CO}_{2}$-fixation reactions.

On the linkage map of Escherichia coli (Taylor \& Thoman, 1964) the succinate and lysine + methionine loci are shown separately, but close together. The one mutant we have tested also maps in this region, and it seems likely that the succinate and lysine + methionine loci are identical.

\section{Arginine and pyrimidine mutants}

The three mutants of Escherichia coli to be described in this section were isolated in penicillin selection experiments in which minimal medium supplemented with arginine, uridine and adenine (Io $\mathrm{mg}$./1. each) was used for the period of intermediate incubation (see Methods). Two of the mutants (AP 2I, B 22) have defects in the biosynthesis of carbamoyl phosphate (CAP) which is a precursor of arginine and pyrimidines. In $E$. coli, CAP for the biosynthesis of these substances is formed by a $\mathrm{CO}_{2}$-incorporation reaction catalysed by the enzyme glutamino-carbamoyl phosphate synthetase (GCPSase; Piérard, Glansdorff, Mergeay \& Wiame, I965). The synthesis of this enzyme is cumulatively repressed by arginine and pyrimidines and its catalytic activity is subject to feedback inhibition by uridine- 5 '-monophosphate (UMP). Ornithine counteracts the inhibition by UMP, a mechanism which ensures that CAP is available for arginine biosynthesis when required (Piérard, 1966). The enzyme is specified by the cap locus (Piérard et al. 1965), which is the same as the pyr A locus of Jacob \& Wollman (196I) and Beckwith, Pardee, Austrian \& Jacob (1962).

The Escherichia coli mutant designated AP 2 I required arginine + a pyrimidine for growth in the absence of supplementary $\mathrm{CO}_{2}$. Arginine was stimulatory in the absence of a pyrimidine when incubation was prolonged for 2-3 days, but growth was never as great as with arginine + a pyrimidine. Arginine was replaceable by citrulline. Pyrimi- 
dines which stimulated the mutant were uracil, uridine, cytosine and cytidine; thymidine was weakly stimulatory; orotic acid and thymine were inactive. The pyrimidines were not stimulatory unless arginine or citrulline was also present. The growth rate of the mutant in minimal medium when the gas phase was supplemented with $20 \%(\mathrm{v} / \mathrm{v})$ $\mathrm{CO}_{2}$ was as good as that of the parental strain.

Escherichia coli mutant B 22 grew in minimal medium when supplied with arginine or citrulline without a pyrimidine, but growth was better when a pyrimidine was also provided. The mutant responded slowly to $\mathrm{CO}_{2}, 2$ days of incubation being necessary for a growth response. Mutant B 22 therefore differed from mutant AP $2 \mathbf{I}$ in its rapid response to arginine (or citrulline) and its slow response to $20 \%(\mathrm{v} / \mathrm{v}) \mathrm{CO}_{2}$.

The growth response of mutants AP 2 I and в 22 to $20 \%$ (v/v) $\mathrm{CO}_{2}$ was inhibited by uracil, uridine, cytosine, cytidine or thymidine. The inhibitions were annulled by arginine or citrulline. The mutants partially resemble the uracil-inhibited mutants U 28 of Gorini \& Kalman (1963) and ura-s of Piérard et al. (1965) which grow in minimal medium and show inhibition by uracil and annulment of this inhibition by arginine.

Transduction experiments showed that the mutations in Escherichia coli mutants AP 2 I and B 22 were at the cap locus which specifies the only $\mathrm{CO}_{2}$-incorporation enzyme (GCPSase) in arginine and pyrimidine biosynthesis. Enzymological studies showed that GCPSase activity was present in the mutants but at a lower concentration than in the parental strain (G. A. Roberts, unpublished). The fact that both mutants grew without a pyrimidine when supplied with arginine suggests that CAP was available for pyrimidine synthesis but not for arginine synthesis. Perhaps the CAPsynthesizing enzyme in the mutants was altered at a regulatory site, so that ornithine no longer counteracted the feedback inhibition by pyrimidines, and arginine synthesis consequently failed through lack of CAP. An explanation of this kind was proposed by Piérard (1966) to explain the uracil inhibition of ura-s. Carbon dioxide may stimulate growth in minimal medium by increasing CAP synthesis, e.g. by a mass action effect or by antagonizing the pyrimidine feedback inhibition, so that sufficient CAP is available for arginine synthesis. A second and quite different possibility is that the increased $\mathrm{CO}_{2}$ concentration may bring into action another CAP-synthesizing enzyme such as 'carbamyl phosphokinase', which is present in $E$. coli but does not provide CAP for arginine and pyrimidine synthesis under the usual cultural conditions (Thorne \& Jones, I963; Yashphe \& Gorini, 1965). This kind of explanation does not account for the pyrimidine inhibitions unless more assumptions are made.

The Escherichia coli mutant M I 2 was stimulated by the pyrimidines uracil, uridine, cytosine or cytidine. The growth response to $\mathrm{CO}_{2}$ was slow and was not inhibited by any common metabolite. Arginine and citrulline were slightly stimulatory to growth in $20 \%(\mathrm{v} / \mathrm{v}) \mathrm{CO}_{2}$. Interrupted mating experiments showed that the mutation was in the region of the pyr $C, D$ and $F$ loci (Beckwith et al. 1962; Taylor et al. 1964). Pyr $C$ and $D$ are close together and some distance from pyr $F$, which is nearer to the try locus (Taylor $1965 ; R$. Lavallé, private communication). Preliminary experiments suggested that the M I2 mutation may be at the pyr $F$ locus which specifies the enzyme orotidylic acid decarboxylase (Beckwith et al. 1962; Taylor \& Thoman, 1964). This mutation was not at the cap locus, which specifies the only $\mathrm{CO}_{2}$-incorporation enzyme in pyrimidine (and arginine) biosyothesis. 


\section{Histidine mutants}

The histidine $/ \mathrm{CO}_{2}$ mutants of Escherichia coli showed a better response to histidine than to $20 \%(\mathrm{v} / \mathrm{v}) \mathrm{CO}_{2}$, suggesting either that adaptation was necessary for utilization of $\mathrm{CO}_{2}$, or that $\mathrm{CO}_{2}$ only partially compensated for the defects in the mutants. In the presence of supplementary $\mathrm{CO}_{2}$, nicotinic acid was stimulatory but it was not stimulatory when the gas phase was ordinary air. This relationship between nicotinic acid and histidine biosynthesis requires further investigation. When growing in $\mathrm{CO}_{2}$ these mutants were completely inhibited by purines. The mutation has not been

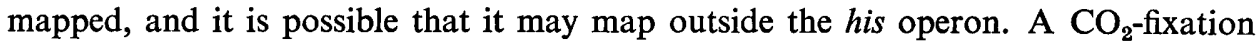
reaction does not occur in the biosynthesis of histidine from its precursor adenosine triphosphate (ATP) so that if $\mathrm{CO}_{2}$ acts by stimulating a $\mathrm{CO}_{2}$-incorporation enzyme it must act on the enzyme catalysing the formation of CAIR from AIR, in the biosynthesis of ATP. But the mutation did not map at the locus which specifies this enzyme, and it seems unlikely that a defect in this enzyme would cause a requirement for histidine unless there are unexpected complexities in purine and histidine biosynthesis. Histidine $/ \mathrm{CO}_{2}$ mutants are not known in Neurospora.

\section{Methionine mutant}

The methionine $/ \mathrm{CO}_{2}$ mutant of Escherichia coli responded vigorously to methionine and more weakly to cysteine. It gave a good response to $\mathrm{CO}_{2}$ within $24 \mathrm{hr}$. When growing with $\mathrm{CO}_{2}$ the mutant was partially inhibited by aspartate and completely inhibited by serine; the parental strain was also inhibited by serine, but not as strongly as was the mutant. Methionine $/ \mathrm{CO}_{2}$ mutants are also known in Neurospora. The ability of $\mathrm{CO}_{2}$ to substitute for methionine in these mutants is not understood.

\section{An obligate $\mathrm{CO}_{2}$ mutant}

One mutant of Escherichia coli was an obligate $\mathrm{CO}_{2}$ mutant in that it did not grow in minimal or complete medium except when the gas phase was supplemented with $\mathrm{CO}_{2}$. In the presence of $20 \%(\mathrm{v} / \mathrm{v}) \mathrm{CO}_{2}$ colonies formed on complete medium within $24 \mathrm{hr}$, but on minimal medium colonies took $48 \mathrm{hr}$ to form. This showed that $\mathrm{CO}_{2}$ itself did not completely compensate for the defect in the mutant. Growth of the mutant in $20 \%(\mathrm{v} / \mathrm{v}) \mathrm{CO}_{2}$ was inhibited by purines and tyrosine. In some experiments the inhibitions were complete but in others they were incomplete. The reason for this variation from experiment to experiment is not known.

Obligate $\mathrm{CO}_{2}$ mutants are also known in Neurospora and some are similarly inhibited by purines (Broadbent, I965; A. Vivian, personal communication.)

\section{DISCUSSION}

This investigation shows that $\mathrm{CO}_{2}$ mutants occur in Escherichia coli as well as in Neurospora. The phenomena which they reveal are therefore likely to be of general occurrence. The parental strains of Neurospora and Escherichia coli from which the mutants have been isolated differ in their $\mathrm{CO}_{2}$ requirements. The Neurospora strains grow when incubated in a desiccator containing potassium hydroxide (100 ml., $25 \%$, w/v) but the Escherichia strains do not, showing that Neurospora requires a much lower concentration of $\mathrm{CO}_{2}$ than Escherichia. A second difference is that growth 
of Neurospora is not inhibited when the gas phase contains $30 \%(\mathrm{v} / \mathrm{v}) \mathrm{CO}_{2}$, whereas Escherichia begins to show inhibition when the gas phase contains more than $20 \%$ $(\mathrm{v} / \mathrm{v}) \mathrm{CO}_{2}$. The differences between the parental strains are reflected in the $\mathrm{CO}_{2}$ mutants. Neurospora $\mathrm{CO}_{2}$ mutants do not grow when incubated in minimal medium in the presence of potassium hydroxide, but they grow when the gas phase contains $30 \%$ (v/v) $\mathrm{CO}_{2}$; when incubated in ordinary air some of the $\mathrm{CO}_{2}$ mutants grow fairly quickly, probably because of the $\mathrm{CO}_{2}$ in the environment and because of accumulation of $\mathrm{CO}_{2}$ by the conidia. In Escherichia, $\mathrm{CO}_{2}$ mutants do not grow when the gas phase is ordinary air and they grow when the gas phase contains $20 \%(\mathrm{v} / \mathrm{v}) \mathrm{CO}_{2}$. The fact that some mutants were obtained only once shows that the samples of mutants isolated were small, and it is likely that more kinds of $\mathrm{CO}_{2}$ mutants await discovery in both Escherichia and Neurospora. This may explain why the patterns of mutants from the two organisms do not match completely, although there is no reason to expect that they should.

Arginine, purine, pyrimidine and succinate mutants occur in both organisms. The mechanism of the $\mathrm{CO}_{2}$ stimulation may be fairly easily understood in some of these $\mathrm{CO}_{2}$ mutants because the relevant biosynthetic pathways all have $\mathrm{CO}_{2}$-incorporation reactions and some of the mutations which have been mapped fall at the loci which specify the appropriate $\mathrm{CO}_{2}$-incorporation enzymes. An unexplained fact is that $\mathrm{CO}_{2}$ mutants occur at three arginine loci in Neurospora. Whether $\mathrm{CO}_{2}$ mutants occur at several arginine loci in Escherichia remains to be investigated. Mutation at the arg-II locus in Neurospora causes simultaneous requirement for arginine, a pyrimidine, a purine and possibly succinate (Newmeyer, 1964; Broadbent \& Charles, 1965). The function of this gene is unknown. The facts that the two known arg-II mutants are both $\mathrm{CO}_{2}$ mutants and that $\mathrm{CO}_{2}$ completely satisfies or annuls all the requirements suggest that the gene may be concerned with a process providing $\mathrm{CO}_{2}$ for arginine, purine, pyrimidine and succinate biosyntheses. Mutants similar to arg-II mutants have not been obtained in Escherichia, but even in Neurospora mutants similar to the $\arg -\mathrm{II}$ mutants were not obtained in $\mathrm{CO}_{2}$-mutant isolation experiments.

With Escherichia we have the best example of a mutant which is completely dependent on a supplement of $\mathrm{CO}_{2}$ and unable to use any other growth factor within a reasonable incubation period. The mutant does not grow on complete medium except when extra $\mathrm{CO}_{2}$ is added to the gas phase. Its requirements may be complex because it responds better to $\mathrm{CO}_{2}$ on complete medium that on minimal medium. The mutant may have a defect in fatty-acid metabolism, because a small proportion of the bacteria respond to oleic acid and Tween 80 after prolonged incubation.

Isoleucine + valine mutants were obtained with Escherichia but not Neurospora. They are of special interest because there is no $\mathrm{CO}_{2}$-incorporation reaction in the biosyntheses of isoleucine and valine; this excludes certain proposed explanations of how $\mathrm{CO}_{2}$ may stimulate mutants.

Tryptophan and acetate mutants are so far known only from Neurospora; the nature of their enzymic deficiencies is not known.

$\mathrm{CO}_{2}$ mutants which require succinate, or lysine + methionine, when not provided with supplementary $\mathrm{CO}_{2}$ have been discussed in the Results section. An interesting question arising from the discovery that succinate mutants are $\mathrm{CO}_{2}$ mutants is whether the reported ability of succinate mutants to grow anaerobically in minimal medium without succinate or lysine + methionine (Davis et al. 1959; Stouthamer, 
1967), may be due to stimulatory concentrations of $\mathrm{CO}_{2}$ in the anaerobic jars, rather than to absence of $\mathrm{O}_{2}$.

The interest of $\mathrm{CO}_{2}$ mutants lies chiefly in their relevance to problems of nutrition and metabolism. It has long been known that some micro-organisms, and probably all, require $\mathrm{CO}_{2}$ for initiation of growth (Valley \& Rettger, 1927; Rockwell \& Highberger, I927; Rahn, I94I). This phenomenon is often referred to as 'the $\mathrm{CO}_{2}$ effect'. $\mathrm{CO}_{2}$ mutants are of special interest in relation to the problems posed by this and other effects of $\mathrm{CO}_{2}$. When it was realized that generation of a 4-carbon compound from a 3-carbon compound by a $\mathrm{CO}_{2}$-fixation reaction was necessary for continuous operation of the Krebs cycle, it seemed that the explanation of 'the $\mathrm{CO}_{2}$ effect' was at hand (Krebs, I94I). However, experiments on nutrition in which attempts were made to replace $\mathrm{CO}_{2}$ with glutamate, aspartate or Krebs cycle intermediates showed that these substances only partly substituted for $\mathrm{CO}_{2}$, if at all; and the more stringent the removal of $\mathrm{CO}_{2}$, or the smaller the inoculum, then the more nutritionally demanding the bacteria became or the longer the lag period before they grew (Lwoff \& Monod, 1946, 1947; Wong \& Ajl, 1953). With the discovery of $\mathrm{CO}_{2}$-fixation reactions in other essential processes such as the biosyntheses of arginine, pyrimidines and purines one might have expected the $\mathrm{CO}_{2}$ effect to be fully explained, but experiments show that in some bacteria it is not possible to replace $\mathrm{CO}_{2}$ with other growth factors, and in other bacteria growth factors which replace $\mathrm{CO}_{2}$ do not have a $\mathrm{CO}_{2}$-fixation reaction in their path of biosynthesis. Other points of interest are: (I) $\mathrm{CO}_{2}$ requirements are not always satisfied by bicarbonates and carbonates; (2) newly isolated pathogenic bacteria may require relatively high concentrations of $\mathrm{CO}_{2}$ for growth, which may lessen after serial transfer; (3) effects of $\mathrm{CO}_{2}$ on morphogenesis are known, for example, high $\mathrm{CO}_{2}$ concentrations cause some filamentous fungi to adopt a yeast-like mode of growth (Bartnicki-Garcia \& Nickerson, 1962), and bring about the development of sex organs in the coelenterate Hydra (Loomis, I96I).

It is sometimes implied that $\mathrm{CO}_{2}$ is required for the initiation rather than the continuation of bacterial growth. It seems more likely that $\mathrm{CO}_{2}$ is required both for initiation and growth, and that when growth has started the bacteria may generate far more $\mathrm{CO}_{2}$ than they use so that it is impossible to demonstrate a net requirement for $\mathrm{CO}_{2}$. Whether $\mathrm{CO}_{2}$ must be absorbed from outside the cell during growth or whether intracellular $\mathrm{CO}_{2}$ may satisfy all the requirements is unknown. It may be that intracellular and extracellular $\mathrm{CO}_{2}$ are freely exchangeable, in which case the distinction between intracellular and extracellular $\mathrm{CO}_{2}$ would be false. This possibility is worth investigation because it would help to explain some aspects of $\mathrm{CO}_{2}$ effects.

All the problems encountered in the study of 'the $\mathrm{CO}_{2}$ effect' are encountered in the study of $\mathrm{CO}_{2}$ mutants; thus bicarbonates and carbonates do not replace $\mathrm{CO}_{2}$. It is uncertain whether $\mathrm{CO}_{2}$ is required for initiation and/or continuation of growth. Inoculum size and lag effects are common and some mutants grow without a supplement of $\mathrm{CO}_{2}$ or growth factors when the inoculum is concentrated or incubation is prolonged. Some mutants do not respond to growth factors other than $\mathrm{CO}_{2}$. Most interesting of all, some $\mathrm{CO}_{2}$ mutants respond in the absence of $\mathrm{CO}_{2}$ from the gas phase to growth factors which do not have $\mathrm{CO}_{2}$-incorporation reactions in their biosyntheses. It seems likely, for all these reasons, that $\mathrm{CO}_{2}$ mutants mimic some of the $\mathrm{CO}_{2}$ effects shown by different bacterial species. $\mathrm{CO}_{2}$ mutants may be the most satisfactory experimental systems for analysing $\mathrm{CO}_{2}$ effects because they show well- 
defined $\mathrm{CO}_{2}$ effects expressed against a common genetic background, and because the biochemical problem is considerably simplified, since each $\mathrm{CO}_{2}$ effect is probably the result of a change in a single enzyme as compared with the parental strain which serves as a control or reference. By contrast, the $\mathrm{CO}_{2}$ effects shown by wild-type organisms may result from peculiarities in several enzymes and there will be no reference strain available to show which enzymic characteristics are responsible for the $\mathrm{CO}_{2}$ effect. That mutants may make other contributions to the understanding of $\mathrm{CO}_{2}$ effects is shown by a recent observation that some mutant strains of Escherichia and Neurospora are inhibited rather than stimulated by $\mathrm{CO}_{2}$; this raises the possibility that some $\mathrm{CO}_{2}$ effects may result from inhibition rather than stimulation of enzymic reactions by $\mathrm{CO}_{2}$ (Roberts \& Charles, unpublished).

This investigation was supported by a research grant from the Agricultural Research Council; thanks are due to the Science Research Council for a research studentship awarded to G.A.R. We thank Mr I. McMurray for technical assistance. The transduction experiments were done with the generous help of Monsieur M. Mergeay at the Institut de Recherches du C.E.R.I.A., Brussels, and we thank Professor J. M. Wiame for welcoming one of us (G.A.R.) to the Institut.

\section{REFERENCES}

AJl, S. J. \& Werkman, C. H. (1949). Anaerobic replacement of carbon dioxide. Proc. Soc. exp. Biol. Med. N.Y. 70, 522.

BACK, K. J. C. \& WestaWAY, E. G. (1962). Studies on a mutant strain of Escherichia coli which requires both methionine and lysine for growth. J. gen. Microbiol. 27, 4I.

BARTNICKI-GARCIA, S. \& Nickerson, W. J. (1962). Induction of yeast-like development in Mucor by carbon dioxide. J. Bact. 84, 829.

Beckwith, J. R., Pardee, A. B., Austrian, R. \& Jacob, F. (1962). Co-ordination of the synthesis of the enzymes in the pyrimidine pathway of E. coli.J. molec. Biol. 5, 618 .

Broadbent, J. A. (1965). Carbon-dioxide Requiring Mutants in Neurospora crassa. Ph.D. thesis, University of Reading, England.

Broadbent, J. A. \& Charles, H. P. (1965). Some carbon-dioxide requiring mutants of Neurospora crassa. J. gen. Microbiol. 34, I3I.

Charles, H. P. (1962). Response of Neurospora mutants to carbon dioxide. Nature, Lond. 195, 359.

Charles, H. P. \& Broadbent, J. A. (1964). Carbon dioxide mutants: a large and interesting class of Neurospora mutants. Nature, Lond. 201, 1004.

DAvis, B. D. \& Mingioli, E. S. (1950). Mutants of Escherichia coli requiring methionine or vitamin B I2. J. Bact. 6o, I7.

Davis, B. D., Kornberg, H. L., Nagler, A., Miller, P. \& Mingioli, E. (1959). Formation and functions of succinate in Escherichia coli. Fedn Proc. Fedn Am. Socs exp. Biol. 18, 2 II.

GILVARG, C. (1957). $N$-succinyl- $L$-diaminopimelic acid, an intermediate in the biosynthesis of diaminopimelic acid. Biochim. biophys. Acta 24, 216.

GLANDSDORFF, N. (1965). Topography of cotransducible arginine mutations in Escherichia coli K-12. Genetics 5I, 167.

Goodgal, H., Margolin, P. \& SANDerson, K. (1964). Laboratory manual for a course: Selected Methods in Bacterial Genetics. Cold Spring Harbor Laboratory for Quantitative Biology, Cold Spring Harbor, New York, U.S.A.

GoRINI, L. \& KaLMAN, S. M. (I963). Control by uracil of carbamyl phosphate synthesis in Escherichia coli. Biochim. biophys. Acta 69, 355.

GoRINI, L. \& KaUfMAN, H. (I959). Selecting bacterial mutants by the penicillin method. Science, N.Y. I3I, 604 .

Gots, J. S. (1965). Personal communication quoted in Stouthamer et al. (1965). 
Hayes, W., JACOB, F. \& Wollman, E. L. (1956). Conjugation in bacteria. In Methodology in Basic Genetics. Ed. by W. L. Burdette, p. I29. San Francisco: Holden-Bay Inc.

IvaNoviCs, G. (1937). Unter welchen Bedingungen werden bei der Nährboden-Züchtung der Milzbrandbazillen Kapseln gebildet. Zbl. Bakt. (I. Abt. Orig.) 138, 449.

JacoB, F. \& Wollman, E. L. (1961). Sexuality and the Genetics of Bacteria. New York: Academic Press.

KreBs, H. A. (194I). Carbon dioxide assimilation in heterotrophic organisms. Nature, Lond. r47, 560.

LEDERBERG, J. \& LEDERBERG, E. M. (1952). Replica plating and indirect selection of bacterial mutants. J. Bact. 63, 399.

Loomis, W. F. (196I). Cell differentiation. A problem in selective gene activation through selfproduced micro-environmental differences of carbon dioxide tension. In Biological Structure and Function. Ed. by T. W. Goodwin and O. Lindberg. New York: Academic Press.

Love S. H. \& Gots J. S. (1955). Purine metabolism in bacteria. III. Accumulation of a new pentosecontaining arylamine by a purine-requiring mutant of Escherichia coli. J. biol. Chem. 212, 647 .

LwOFF, A. \& MONOD, J. (1946). L'anhydride carbonique considéré comme substance indispensable aux micro-organismes. La biosynthèse des acides dicarboxyliques. C. r. hebd. Séanc. Acad. Sci., Paris 222, 696.

LwoFf, A. \& MONOD, J. (1947). Essai d'analyse du rôle de l'anhydride carbonique dans la croissance microbienne. Annls Inst. Pasteur, Paris 73, 323.

NewMEYER, D. (1964). Growth and allelism of arg-II and adg. Neurospora Newsletter 6, I4.

PÍ́RARD, A. (1966). Control of the activity of Escherichia coli carbamoyl phosphate synthetase by antagonistic allosteric effectors. Science, N.Y. 154, 1572.

Piérard, A., Glansdorff, N., Mergeay, M. \& Wiame, J. M. (1965). Control of the biosynthesis of carbamoyl phosphate in Escherichia coli. J. molec. Biol. 14, 23.

PonteCoRvo, G. J. (1949). Auxanographic techniques in biochemical genetics. J. gen. Microbiol. 3, I 22.

RAHN, O. (I94I). Protozoa need carbon dioxide for growth. Growth 5, 197.

Ramakrishnan, T. \& AdelBerg, E. A. (1964). Regulatory mechanisms in the biosynthesis of isoleucine and valine. I. Genetic derepression of enzyme formation. J. Bact. 87, 566.

Ramakrishnan, T. \& Adelberg, E. A. (1965a). Regulatory mechanisms in the biosynthesis of isoleucine and valine. II. Identification of two operator genes. J. Bact. 89, 654 .

RAMAKRISHNAN, T. \& ADELBERG, E. A. (1965b). Regulatory mechanisms in the biosynthesis of isoleucine and valine. III. Map order of the structural genes and operator genes. J. Bact. 89, 66 I.

Rockwell, G. E. \& Highberger, J. H. (1927). The necessity of carbon dioxide for the growth of bacteria, yeasts and molds. J. inf. Dis. 40, 438.

RowBURY, R. J. \& WooDs, D. D. (1964). $O$-succinyl-homoserine as an intermediate in the synthesis of cystathionine by Escherichia coli. J. gen. Microbiol. 36, 34I.

Reissig, J. L. \& NaZARIo, M. (1962). Regulación genetica de la sintesis de arginia y uridina. Sesiones Cientificas de Biologica Cordoba (Argentina), p. 76.

Stoutamer, A. H. (1967). Mutant strains of Aerobacter aerogenes which require both methionine and lysine for aerobic growth. J. gen. Microbiol. 46, 389.

Stouthamer, A. H., De HAan, P. G. \& NiJKamp, H. J. J. (1965). Mapping of purine markers in Escherichia coli $\mathrm{K}$ 12. Genet. Res. 6, 442.

TAYLOR, A. L. (1965). Quoted in Yan, Y. \& Demerec, M. Genetic analysis of pyrimidine mutants of Salmonella typhimurium. Genetics 52, 643.

TAYlor, A. L. \& Thoman, M. S. (1964). Genetic map of Escherichia coli K I2. Genetics 50, 659.

TAYlor, A. L., Beckwith, J. R., Pardee, A. B., Austrian, R. \& JACOB, F. (1964). The chromosomal location of the structural gene for orotidylic acid pyrophosphorylase in Escherichia coli. J. molec. Biol. 8, 77 I.

Thorne, K. J. I. \& Jones, M. E. (1963). Carbamyl and acetyl phosphokinase activities of Streptococcus faecalis and Escherichia coli. J. biol. Chem. 238, 2992.

Topley and Wilson's Principles of Bacteriology and Immunity. (1964). 5th ed. Ed. by G. S. Wilson and A. A. Miles, p. 83. London: Edward Arnold Ltd.

Valley, G. \& ReTtGeR, L. F. (1927). The influence of carbon dioxide on bacteria. J. Bact. 14, IOI. 
VoGel, H. J. \& BonNer, D. M. (1956). A convenient growth medium for $E$. coli and some other organisms. Microb. Genet. Bull. 13, 43.

Wong, D. T. O. \& AJL, S. J. (1953). Replacement of carbon dioxide by factors obtained from Lebedev juice. Expl. Cell Res. 4, 42.

YASHPHE, J. \& GORIN, L. (1965). Phosphorylation of carbamate in vivo and in vitro. J. biol. Chem. $240, \mathrm{I} 68 \mathrm{r}$. 